Tomcsik, J. \& Grace, J. B. (1955). J. gen. Microbiol. 13, 105-110.

\title{
Bacterial Cell Walls as Revealed by the Specific Cell- wall Reaction and by Direct Staining with Alcian Blue
}

\author{
By J. TOMCSIK \\ Institute for Hygiene and Bacteriology, University of Basel, Switzerland \\ AND JOYCE B. GRACE \\ Department of Bacteriology, University of Birmingham
}

SUMMARY : Isolated cell walls of strains of Bacillus, Micrococcus and Caryophanon species obtained by mechanical disintegration, and in some instances by the action of trypsin, gave a specific cell-wall reaction, visible in the phase-contrast microscope on the addition of homologous antibody. The cell-wall structure, as revealed in the specific cell-wall reaction, is very similar to that observed in stained preparations. A method is described for staining the bacterial cell wall with Alcian blue without preliminary treatment with a mordant.

Tomesik \& Guex-Holzer (1952, 1954a) showed that when the cell wall of 'Bacillus M' was separated from the cytoplasm by the action of trypsin or lysozyme, it could be made visible to phase-contrast microscopy by reaction with an antibody specific for a bacillary polysaccharide. This phenomenon, designated the specific cell-wall reaction, was also observed in B. anthracis but only after prior treatment with trypsin (Tomcsik, 1954). Many bacteria, however, cannot be digested with lysozyme or trypsin and one purpose of the present investigation was, therefore, to determine whether this reaction occurred in cell walls obtained by mechanical disintegration (Salton \& Horne, 1951).

The standard cytological methods for the demonstration of the bacterial cell wall entail the use of a mordant followed by the application of a basic dye (Robinow, 1946; Hale, 1953; Bisset \& Hale, 1953). Recently, Alcian blue has been recommended as a stain for bacterial capsules (Novelli, 1953). We have found, however, that Alcian blue will stain the cell walls of many bacteria without the use of a mordant. In this study we have used these staining methods in parallel with the specific cell-wall reaction to compare the cell walls of intact bacteria with those obtained after enzymic or mechanical disruption.

\section{METHODS}

Organisms. The following strains of bacteria were selected for examination, partly on account of their notably multicellular morphology: Bacillus M described by Tomesik \& Guex-Holzer (1951, 1954a, b); Bacillus anthracis strain Vollum, NCTC 7200; B. megaterium, strain I from Dr J. P. Aubert, Institut Pasteur, and strain II from Dr S. Raffel, Stanford University, California, U.S.A.; Micrococcus sp., strains A and B; Caryophanon latum from Dr K. A. Bisset, University of Birmingham. 
Culture media. Caryophanon latum was grown on agar containing $\mathbf{0 . 5} \%$ (w/v) Difco peptone, $0.5 \%$ yeast extract and $0.01 \%$ sodium acetate. The other bacteria were grown on Gladstone \& Fildes CCY agar or broth, without the addition of glucose. The capsulated cells of Bacillus M were obtained from cultures grown on the agar at $28^{\circ}$ and the non-capsulated form from the broth which was aerated for $10-18 \mathrm{hr}$. at $28^{\circ}$.

Antibodies. The polysaccharide antibody against Bacillus M and the Dglutamic acid polypeptide antibody were those described in a previous work (Tomesik \& Guex-Holzer, 1954a). The homologous antibodies against B. megaterium, B. cereus, Micrococcus spp. and Caryophanon latum were produced by the intravenous inoculation of rabbits with 10 doses of living suspensions at 3-4-day intervals. Heat-killed suspensions were used in the case of $B$. anthracis. The animals were bled 8 days after the last injection.

Alcian blue. Obtained from Imperial Chemical Industries Ltd., Manchester.

Mechanical disintegration of the cells. Isolated cell walls were obtained by a method similar to that used by Salton \& Horne (1951). One volume of smooth beads of average diameter $0.2 \mathrm{~mm}$. was added to three volumes of a thick bacterial suspension and the whole shaken for 10-120 min. in a Mickle disintegrator until $90 \%$ of the cells were free from protoplasts when examined microscopically. The amplitude of vibration was kept constant for each species. The isolated cell walls were then washed with physiological saline.

Trypsin digestion. Two commercial preparations of trypsin were used: Trypsin I (Merck, Darmstadt) and trypsin II (Siegfried, Zofingen). Ten mg. trypsin were suspended in $1.0 \mathrm{ml}$. phosphate buffer ( $\mathrm{pH} 8.0$ ). Three ml. of a similarly buffered bacterial suspension, the turbidity of which corresponded to tube 4 of the $\mathrm{McF}$ arland $\mathrm{BaSO}_{4}$ series (Stitt, Clough \& Clough, 1939), was added together with $1 \mathrm{ml}$. chloroform. The suspension was incubated at $37^{\circ}$ for 10-18 hr., the degree of digestion being determined by phase-contrast microscopy.

Lysozyme digestion was carried out by the method of Tomcsik \& GuexHolzer (1952).

Phase-contrast preparations for the specific cell-wall reaction were made as described by Tomesik \& Guex-Holzer $(1954 a)$. The currents set up in the wet mount by the addition of the serum removed many of the cell walls from the cover glass and made difficult the preparation of serial photomicrographs of the same cells before and after the addition of antiserum (PI. 2, figs. 11, 12).

Staining methods. The cells were fixed, when not otherwise stated, for 2-3 min. in the vapour from $1.0 \%$ osmic acid. The cell walls were stained by the tannic acid violet method (Robinow, 1946), by the phosphomolybdic acid + methyl green method (Hale, 1953), and by the following modification of the technique described by Novelli (1953): smears prepared on coverslips were either allowed to dry in the air or were fixed with osmic acid vapour. An ethanolic solution of the stain (Alcian blue $1 \mathrm{~g}$. in $100 \mathrm{ml} .95 \%$ ethanol) was diluted 1/10 with distilled water and the coverslips immersed in it for 5-10 min., except with Caryophanon latum, the cell wall of which required 30-45 min. Preparations were then washed and mounted in water. 


\section{RESULTS}

The specific cell-wall reaction was elicited after enzymic or mechanical disintegration. Treatment of Bacillus $\mathbf{M}$ with lysozyme separated the cell wall from the protoplast and consequently gave a very clear-cut demonstration of the specific cell-wall reaction on the addition of polysaccharide antibody (Tomcsik \& Guex-Holzer, 1952, 1954 $a, b$ ). With the exception of B. megaterium, however, the bacteria examined were resistant to the action of lysozyme and this method could not be applied to them. Similarly, no digestion of the cells of $B$. cereus and Micrococcus spp. was observed after treatment with trypsin, and only variable results were obtained with Caryophanon latum. There was, however, a marked destruction of the cytoplasm of Bacillus $\mathbf{M}$, B. megaterium and $B$. anthracis with trypsin, and a characteristic morphological change was observed by phase contrast which was quite distinct from that produced by crystalline ribonuclease (Mann Research Laboratories). The cell walls and the remainder of the cell contents were indistinct (Pl. 2, fig. 10), although the contents could still be stained clearly by carbol fuchsin (Pl. 2, fig. 9). Homologous antibody, however, produced a strong specific cell-wall reaction (Pl. 2, figs. 10-12).

In contrast to their varied susceptibility to enzymes, the cell walls of all the bacteria examined were consistently separable by shaking the cells in a Mickle disintegrator, although the time required to obtain a $90 \%$ yield varied considerably with the strain. Micrococcus A, for example (Pl. 3, fig. 19c) a capsulated strain, required 120 min., Micrococcus B 30 min. The cell wall broke more often in Bacillus cereus and in B. anthracis than in Bacillus $\mathbf{M}$.

The cell walls of Bacillus $\mathbf{M}$ obtained by this method differed from those of the other bacteria in that they were barely visible in the phase-contrast microscope until after the addition of antibody. Those of B. anthracis and $B$. cereus, however, were distinctly seen, although their visibility was enhanced by the addition of antibody (Pl. 2, figs. 13-16). The cell walls of Caryophanon latum and particularly those of the Micrococcus spp. were so clearly visible after mechanical disintegration that no appreciable thickening could be observed after the addition of homologous antiserum (Pl. 3, figs. 18, 21 and 22), although it contained enough antibody to agglutinate intact cells in dilutions of $1 / 160$ and 1/1024, respectively. Large, spherical cytoplasmic masses were occasionally observed in cell-wall preparations of $C$. latum after the addition of serum, suggesting that a weakening or lesion of the cross-walls had been followed by the fusion of two or three intact protoplasts (Pl. 3, figs. 22, 23). Swelling of material that revealed septation in the form of a Maltese cross (Pl. 3, fig. 19) was observed in the cocci about $1 \mathrm{hr}$. after the addition of the serum. There was very little cross-agglutination between Micrococcus $\mathrm{A}$ and $\mathrm{B}$, and the cell-wall reaction was specific.

Cell-wall staining. The cell walls and transverse septa of all the bacteria examined could be stained with Alcian blue without preliminary mordanting. The staining was, however, usually very weak (Pl. 1, figs. 6, 8; Pl. 3, fig. 17) and lacked the distinctness and brilliance obtained by standard methods 
(Pl. 1, figs. 5, 7). The very distinct cell-wall structure of Caryophanon latum seen in Pl. 3, fig. 20, was obtained by prolonged staining (40 min.) and the use of an orange filter for photography. In cell walls separated from the intact protoplast by mild lysozyme digestion, both the cell wall and the membrane were apparently stained by Alcian blue (Pl. 1, fig. 8) and by Hale's method (Pl. 1, fig. 7).

The cell-wall structure revealed by the specific cell-wall reaction was very similar to that elicited by staining. The capsular transverse septa of Bacillus $\mathbf{M}$, however, could be demonstrated only with polysaccharide antisera and could not be stained by any of the methods used in this study (Pl. 1, figs. 1, 2). An indistinct capsule could be demonstrated with Alcian blue (PI. 1, fig. 4), but it resembled that obtained after reaction with polypeptide antibody (Pl. 1, fig. 3).

\section{DISCUSSION}

Our observations show that the specific cell-wall reaction originally applied to Bacillus $\mathbf{M}$ can be elicited in a variety of bacteria including Caryophanon latum. We consider that this reaction may be of value, therefore, in the investigation of the mode of action of immunochemically defined antibodies on bacteria as well as in the location of serologically active substances within the cell.

The specific cell-wall reaction demands a preliminary treatment of the bacteria in order to separate the cell wall from the cytoplasm. Previous observations (Tomcsik \& Guex-Holzer, 1954a), as well as those described here, are contrary to the general concept based on the work of Kantorowicz (1909) and Salton (1953) that neither living nor heat-killed cells of Gram-positive bacteria can be digested to any extent with trypsin. The present work suggests, however, that a re-investigation of this question is necessary since the cell contents of three of the five Gram-positive bacteria we studied, Bacillus $\mathbf{M}$, $\boldsymbol{B}$. megaterium and $\boldsymbol{B}$. anthracis, were markedly digested by trypsin, whereas $B$. cereus and species of Micrococcus were resistant to this enzyme. The effect of trypsin on these species of Bacillus cannot be regarded as of universal application until a more representative number of strains has been examined. Experimental evidence (Tomcsik \& Guex-Holzer, 1954c) suggests that there is a thermolabile protein on the surface of Bacillus $\mathbf{M}$ which is readily destroyed by trypsin, and consequently its removal might afford direct access of the trypsin to the protoplast.

The separation of the cell walls by mechanical disintegration by the method of Salton \& Horne (1951) does not alter essentially the morphological appearance of the cell-wall structure. The cross-walls of the Bacillus spp. are almost unaltered, although chain breakage and fissures in the cell walls can often be seen by the phase-contrast microscope. A similar observation was made by Mudd, Polevitzky, Anderson \& Chambers (1941) in their electron micrograph studies of bacilli treated in a sonic oscillator, although comparison of their photomicrographs with ours suggests that by their method there was considerably less destruction of the protoplasts. Murray \& Robinow (1952) obtained similar results with cells of $\boldsymbol{B}$. cereus that had been accidentally crushed with cover-glass forceps. By mechanical disintegration, the two 
right-angled cross-walls of Micrococcus spp. discovered by Bisset (1948, 1954) in stained preparations were readily demonstrated by phase contrast without the addition of antibodies.

The appearance of the cell walls after staining with Alcian blue was essentially similar to that obtained by the standard methods which involve mordanting. Eisenberg (1910) assumed that mordants such as tannic acid and mercuric chloride react with the surface proteins of the bacterial cytoplasm (Endoplasma) and that subsequent staining is restricted to the cell wall (Membran) and the cytoplasmic membrane (Rindenschicht). Using a new method, Robinow \& Murray (1953) have demonstrated that both the cell wall and membrane are stained after treatment with mordants. Bisset (1953) is of the opinion that the cell membrane as such is probably destroyed during mordanting and that the basophilic elements are precipitated upon the wall. Both views may well be correct

It can be seen from the two photomicrographs (Pl. 1, figs. 7, 8) that when the cell wall and cytoplasmic membrane of Bacillus $\mathbf{M}$ are separated by mild lysozyme digestion, both structures are stained by Alcian blue. The staining of the cell wall may represent a microchemical polysaccharide reaction. McKinney (1953) has shown that of a number of organic substances, only carbohydrates retained the dye when it was applied in a $95 \%$ ethanolic solution. The recent report of Grula \& Hartsell (1954) that Alcian blue stains the cell wall of Micrococcus lysodeikticus, is also consistent with this view. The staining of the surface of the cytoplasm after the separation of the protoplast may be due, however, to the protein precipitating action of the dye.

\section{REFERENCES}

Bisset, K. A. (1948). The cytology of the Gram-positive cocci. J. Bact. $2,126$.

Bisset, K. A. (1953). Bacterial cell envelopes. In Bacterial Cytology, Symp. Congr. int. Microbiol. p. 9.

Bisset, K. A. (1954). The cytology of Micrococcus cryophilus. J. Bact. 67, 41.

Bisset, K. A. \& Hale, C. M. F. (1953). Complex cellular structure in bacteria. Exp. Cell. Res. 5, 449.

Eisenberg, P. (1910). Studien zur Ektoplasmatheorie. III. Weitere Methoden zur Darstellung des Ektoplasmas. Zbl. Bakt. (1. Abt.), 53, 481.

Grula, E. A. \& Hartsell, S. E. (1954). Lysozyme and morphological alterations induced in Micrococcus lysodeikticus. J. Bact. 68, 171.

HaLe, C. M. F. (1953). The use of phosphomolybdic acid in the mordanting of bacterial cell walls. Lab. Pract. 2, 11 5.

Kantorowicz, A. (1909). Bakterien-Antifermente und Bakteriolyse. Münch. Med. Wschr. 56, 897.

McKinney, R. E. (1953). Staining bacterial polysaccharides. J. Bact. 66, 453.

Mudd, S., Polevitzky, K., Anderson, T. F. \& Chambers, L. A. (1941). Bacterial morphology as shown by the electron microscope. II. The bacterial cell-wall in the genus Bacillus. J. Bact. 42, 251.

Murray, R. G. E. \& Robinow, C. F. (1952). A demonstration of the cell wall of Bacillus cereus. J. Bact. 63, 298.

Novelur, A. (1953). New methods of staining of bacterial capsules in films and sections. Experientia, 9, 34.

Robinow, C. F. (1946). Addendum to R. J. Dubos: The Bacterial Cell. Cambridge, Mass.: Harvard University Press. 
Robinow, C. F. \& MUrray, R. G. E. (1953). The differentiation of cell wall, cytoplasmic membrane and cytoplasm of Gram-positive bacteria by selective staining. Exp. Cell Res. 4, 390.

SAlton, M. R. J. (1953). Cell structure and the enzymic lysis of bacteria. J. gen. Microbiol. 9, 512.

SAlton, M. R. J. \& Horne, R. W. (1951). Studies of the bacterial cell wall. II. Methods of preparation and some properties of cell walls. Biochim. Biophys. Acta, 7, 177.

Stitt, E. R., Clough, P. W. \& Clough, M. C. (1939). Practical Bacteriology Haematology and Animal Parasitology, 9th ed., p. 261. London: H. K. Lewis.

Tомсsıк, J. (1954). Über die Oberflächenstrukturen des Bacillus anthracis. Schweiz. Z. allg. Path. 17, 457.

Tomcsik, J. \& Guex-Holzer, S. (1951). Anthrax-Polypeptid und andere speziesspezifische Substanzen der Kapsel in der Bazillus-Gruppe. Schweiz. Z. allg. Path. 14, 515.

Tomcsik, J. \& Guex-Holzer, S. (1952). Änderung der Strukter der Bakterienzelle im Verlauf der Lysozym Einwirkung. Schreeiz. Z. allg. Path. 15, 517.

Tomcsik, J. \& Guex-Holzer, S. (1954a). A specific cell-wall reaction in Bacillus sp. J. gen. Microbiol. 10, 317.

Tomcsik, J. \& Guex-Holzer, S. (1954b). Genese der komplexen Kapselstruktur. Schweiz. Z. allg. Path. 17, 221.

Tomcsik, J. \& Guex-Holzer, S. (1954c). Antikörperproduktion mit isolierter Bakterienzellwand und mit Protoplasten. Experientia, 10, 484.

\section{EXPLANATION OF PLATES}

All plates at $\times 2000 . \quad$ ph.c. $=$ phase-contrast.

Plate 1

Fig. 1. Capsulated Bacillus M, ph.c., no antibody.

Fig. 2. Capsulated Bacillus M, ph.c., polysaccharide antibody.

Fig. 3. Capsulated Bacillus $M$, ph.c., first polysaccharide, afterwards polypeptide antibody (the same microscopic field as in Fig. 2).

Fig. 4. Capsulated Bacillus M, Alcian blue.

Fig. 5. Non-capsulated Bacillus $\mathbf{M}$, tannic-acid-violet.

Fig. 6. Non-capsulated Bacillus M, Alcian blue.

Fig. 7. Non-capsulated Bacillus $M$, treated with 1:400 egg-white at room temperature, 25 min. Hale's cell wall stain.

Fig. 8. Same as Fig. 7. Alcian blue.

\section{Plate 2}

Fig. 9. Non-capsulated Bacillus $\mathbf{M}$, digested with trypsin. Alcian blue, carbol fuchsin.

Fig. 10. Non-capsulated Bacillus $M$, digested with trypsin, ph.c. Polysaccharide antibody.

Fig. 11. Non-capsulated Bacillus $M$, digested with trypsin, ph.c. No antibody.

Fig. 12. The same microscopic field as in fig. 11, ph.c. Polysaccharide antibody.

Fig. 13. B. cereus, Mickle-vibrator 15 min. ph.c. No serum.

Fig. 14. B. cereus, Mickle-vibrator $15 \mathrm{~min}$. ph.c. Homologous serum.

Fig. 15. B. anthracis, Mickle-vibrator 15 min. ph.c. No antibody.

Fig. 16. B. anthracis, Mickle-vibrator 15 min. ph.c. Polysaccharide antibody.

Fig. 17. Coccus A, Alcian blue.

\section{Plate 3}

Fig. 18. Coccus A, Mickle-vibrator 2 hr. 20 min., ph.c. No serum.

Fig. 19. Coccus A, Mickle-vibrator 2 hr. 20 min., ph.c. Homologous serum.

Fig. 20. Caryophanon latum, Alcian blue, orange filter.

Fig. 21. C. latum, Mickle-vibrator 20 min., ph.c. Homologous serum.

Fig. 22. Same as Fig. 21, ph.c., showing one large spherical protoplast.

Fig. 23. C. latum with homologous serum, $4 \mathrm{hr}$. in wet chamber. An unusual form with spherical elements. 
Journal of General Microbiology, Vol. 13, No. 1
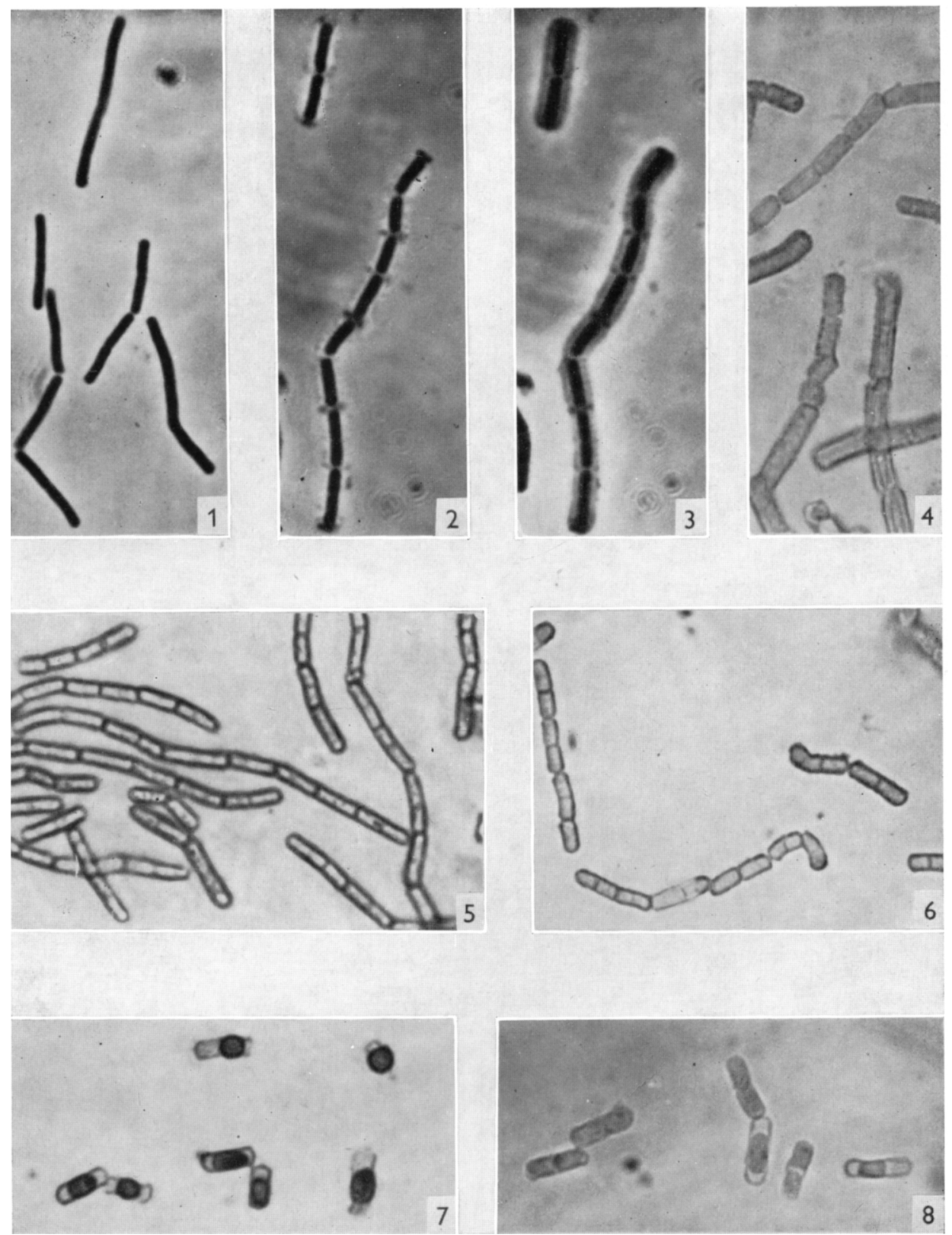

J. Tomcsik and J. B. Grace-Cell wall reactions. Plate 1 
Journal of General Microbiology, Vol. 13, No. 1
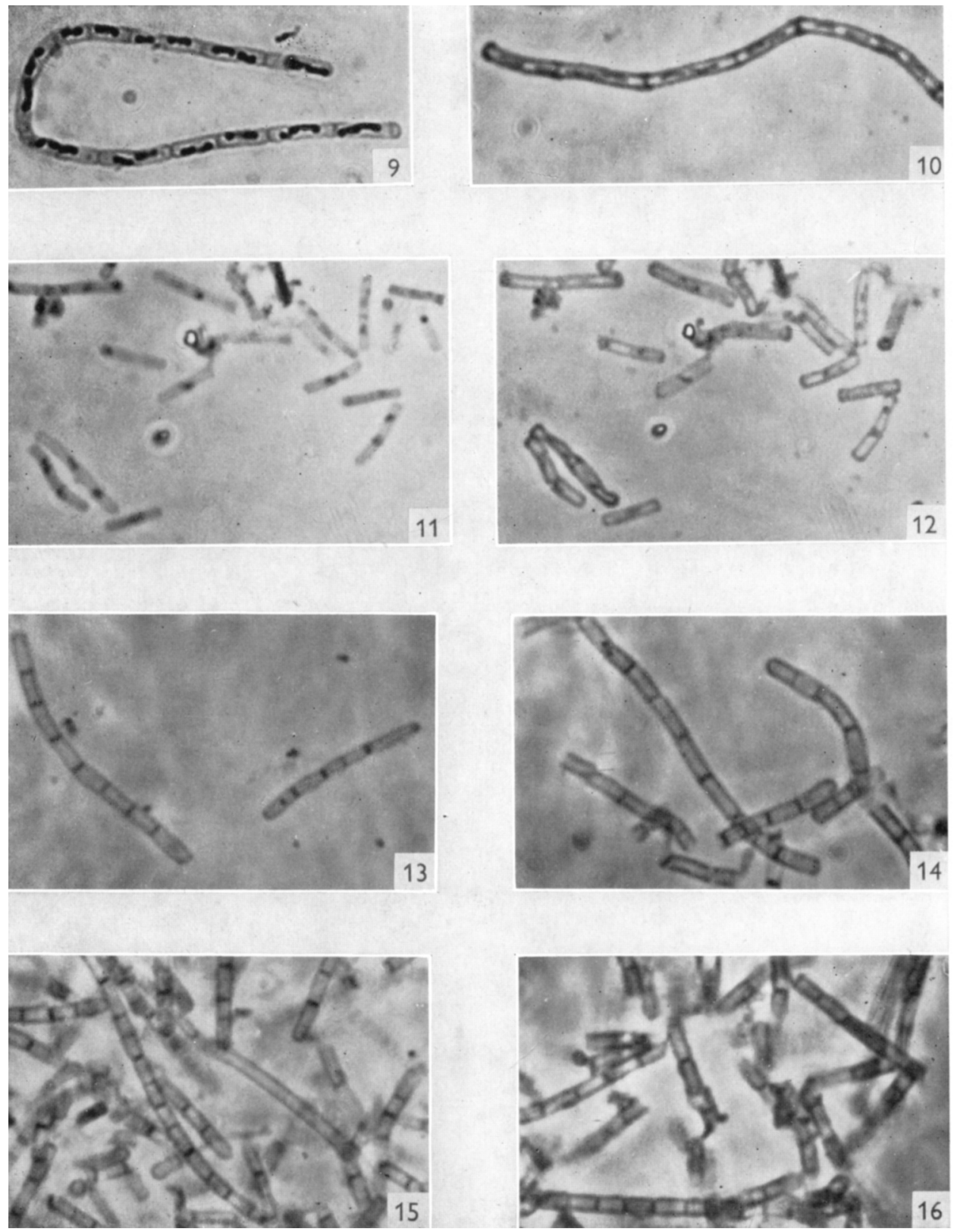

J. Tomcsik and J. B. Grace-Cell wall reactions. Plate 2 
Journal of General Microbiology, Vol. 13, No. 1
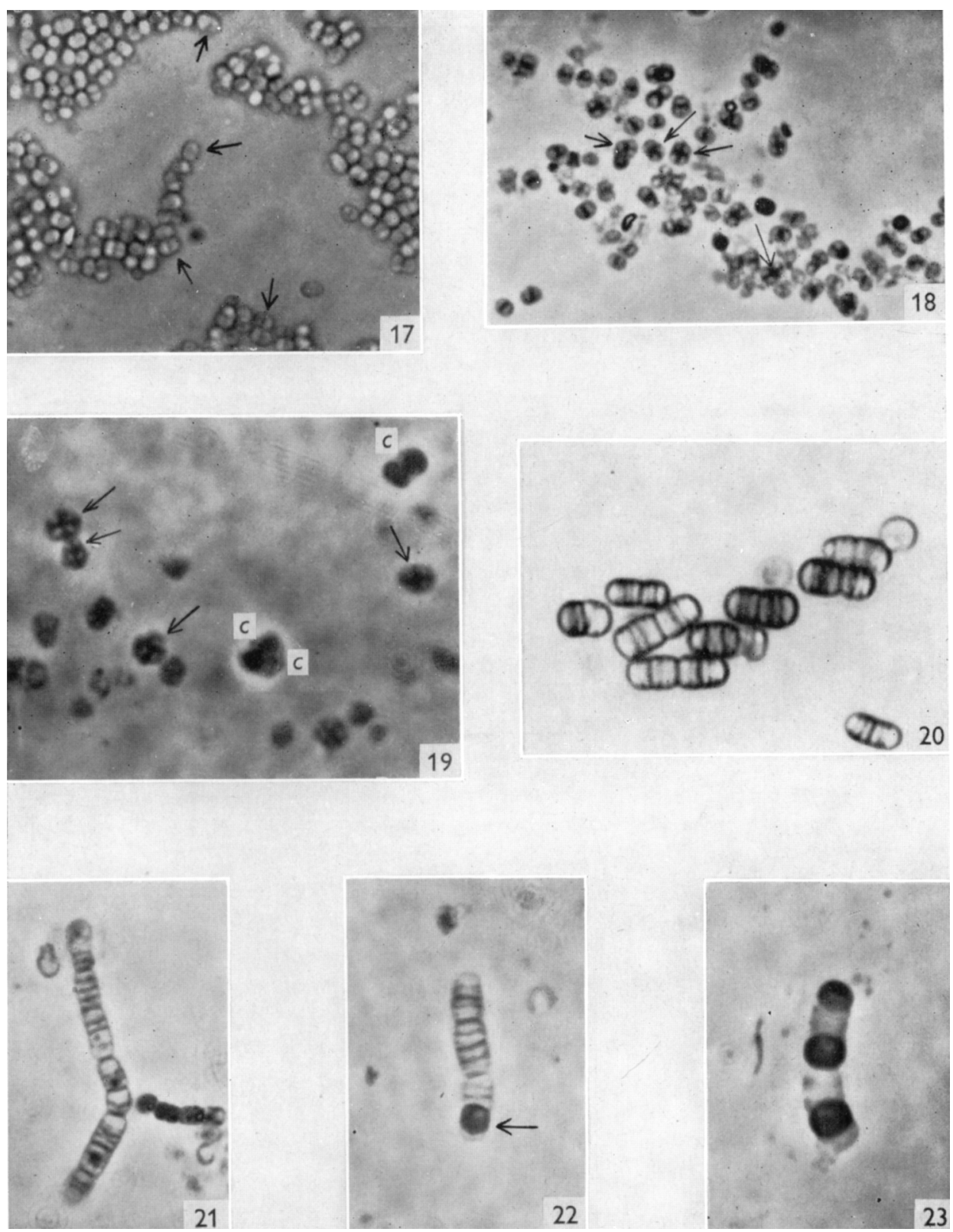

J. Tomcsik and J. B. Grace-Cell wall reactions. Plate 3 